УДК 336.2

DOI: https://doi.org/10.37320/2415-3583/17.15

Яструбецька Л.С. кандидат економічних наук, доцент Львівський національний університет імені Івана Франка

\title{
КОМПЛЕКСНА МЕТОДИКА ОЦІНКИ РІВНЯ ФІНАНСОВОЇ БЕЗПЕКИ СУБ'ЄКТІВ ПІДПРИЕМНИЦТВА В УКРАЇНІ ЗА УМОВ ГІБРИДНИХ ЗАГРОЗ
}

В умовах пандемї COVID-19 суттєвих змін зазнали як світова економічна система, так і фінансова система кожної держави та ділової одиниці зокрема. Карантинні заходи сприяли ще більш стрімкому впровадженню інформаційних технологій у фінансові процеси, зумовивши виникнення оновленого формату функиіонування суб'єктів підприємництва з одночасним поширенням і нових гібридних загроз їх фінансовій безпеці. У иьому контексті у статті обтрунтовано необхідність ефективного управління фінансовою безпекою суб'єктів підприємництва, ключовим етапом якого є оцінка рівня фінансової безпеки. Здійснено порівняльний аналіз різних наукових підходів до такої оцінки та запропоновано авторське бачення даного управлінського процесу. Зокрема, акиентовано на необхідності зважання під час оцінки фінансової безпеки не лише фінансові показники підприємства, а й на якісні параметри кожного зі складників фінансової безпеки. Окрім того, акцентовано на важливості врахування під час оцінки фінансової безпеки суб'єктів господарювання принципів системності, інтегрованості, доступності, конструктивності та стратегічного бачення. Формалізовано сукупність етапів та заходів оцінки фінансової безпеки підприємств у вигляді організаційної моделі, яка дасть змогу підвищити ефективність управління фінансовою безпекою ділових одиниць та зменшити трудові та часові затрати на його реалізацію.

Ключові слова: фінансова безпека суб'єктів підприємництва, оцінка рівня фінансової безпеки підприємств, матриия динамічної фінансової рівноваги, чистий грошовий потік підприємства в розрізі операційної, фінансової, інвестииійної діяльності, організаційна модель очінки рівня фінансової безпеки суб' 'єктів господарювання.

Постановка проблеми. У мінливих умовах ринкового середовища, що значною мірою ускладнюються скрутним економічним становищем у країні внаслідок пандемії COVID-19, перед кожним суб'єктом господарювання гостро стоїть питання ефективного управління його фінансовою безпекою, адже сьогодні ведення підприємницької діяльності супроводжується численними загрозами гібридного характеру. 
Карантинні заходи одночасно зі зростанням інформатизації економіки зумовили виникнення нового формату функціонування суб'єктів підприємництва та ще більше актуалізували потребу розроблення дієвих методів ідентифікації та протидії численним загрозам їхній фінансовій безпеці. Це, своєю чергою, обгрунтовує необхідність формування адекватного вимогам сьогодення, інструментарію оцінки рівня фінансової безпеки ділових одиниць.

Аналіз останніх досліджень і публікацій. Теоретико-методологічні аспекти управління фінансовою безпекою підприємств є предметом дослідження в наукових роботах О. Барановського, 3. Варналія, А. Єпіфанова, О. Підхомного, В. Предборського та ін. Над питаннями оцінки фінансової безпеки суб'єктів господарювання працювали вітчизняні та зарубіжні науковці, зокрема О. Ареф'єва, І. Бланк, Т. Загорельська, С. Ілляшенко, М. Кокнаєва, І. Мойсеєнко, Л. Чаговець та ін. Водночас індикатори фінансової безпеки підприємств та методичні підходи до її оцінки й досі залишаються дискусійними, а розроблення ефективних заходів протидії загрозам фінансовій безпеці суб'єктів господарювання вимагає об'єктивної інформації про рівень їхньої фінансової безпеки.

Мета статті полягає в обгрунтуванні необхідності пошуку сучасних інструментів здійснення такої оцінки з урахуванням гібридних загроз.

Виклад основного матеріалу. Оцінка фінансової безпеки суб'єкта господарювання - це сукупність послідовних дій, тісно взаємопов'язаних між собою щодо аналізу його зовнішнього та внутрішнього середовища $з$ метою виявлення загроз реалізації визначених фінансових інтересів. Універсальної системи оцінки рівня фінансової безпеки на підприємстві, безперечно, немає, адже кожен суб'єкт господарювання має свої особливості, тому повинен іiі розробляти з урахуванням масштабів і специфіки своєї діяльності. Водночас методика такої оцінки, на нашу думку, повинна базуватися на таких ключових принципах:

- системності (узагальнений показник рівня фінансової безпеки підприємства має складатися з окремих оцінок її складників);

- інтегрованості (оцінка окремих складників фінансової безпеки повинна здійснюватися на основі опрацювання значного обсягу інформації, що отримується з різних джерел);

- доступності (дані для здійснення такої оцінки повинні бути легко доступними для отримання);

- конструктивності (оцінка здійснюється з метою вдосконалення параметрів фінансової діяльності, а не лише заради виявлення прогалин фінансової безпеки, за які відповідальні окремі служби чи працівники підприємства);

- стратегічного бачення (показники, що застосовуються для оцінки рівня фінансової безпеки, повинні враховувати стратегічні цілі розвитку підприємства).

Формалізація організаційних процедур оцінки фінансової безпеки підприємств дасть змогу підвищити ефективність управління їхньою фінансовою безпекою, зменшити трудові та часові затрати на його реалізацію, що в підсумку допоможе зміцнити їхню фінансову стійкість, мінімізувати фінансові втрати внаслідок деструктивного впливу чинників внутрішнього та зовнішнього середовища, запобігти протиправним захопленням чи випадкам недобросовісної конкуренції. Пропонуємо організаційну модель такої оцінки, яка включає послідовність таких етапів (рис. 1):

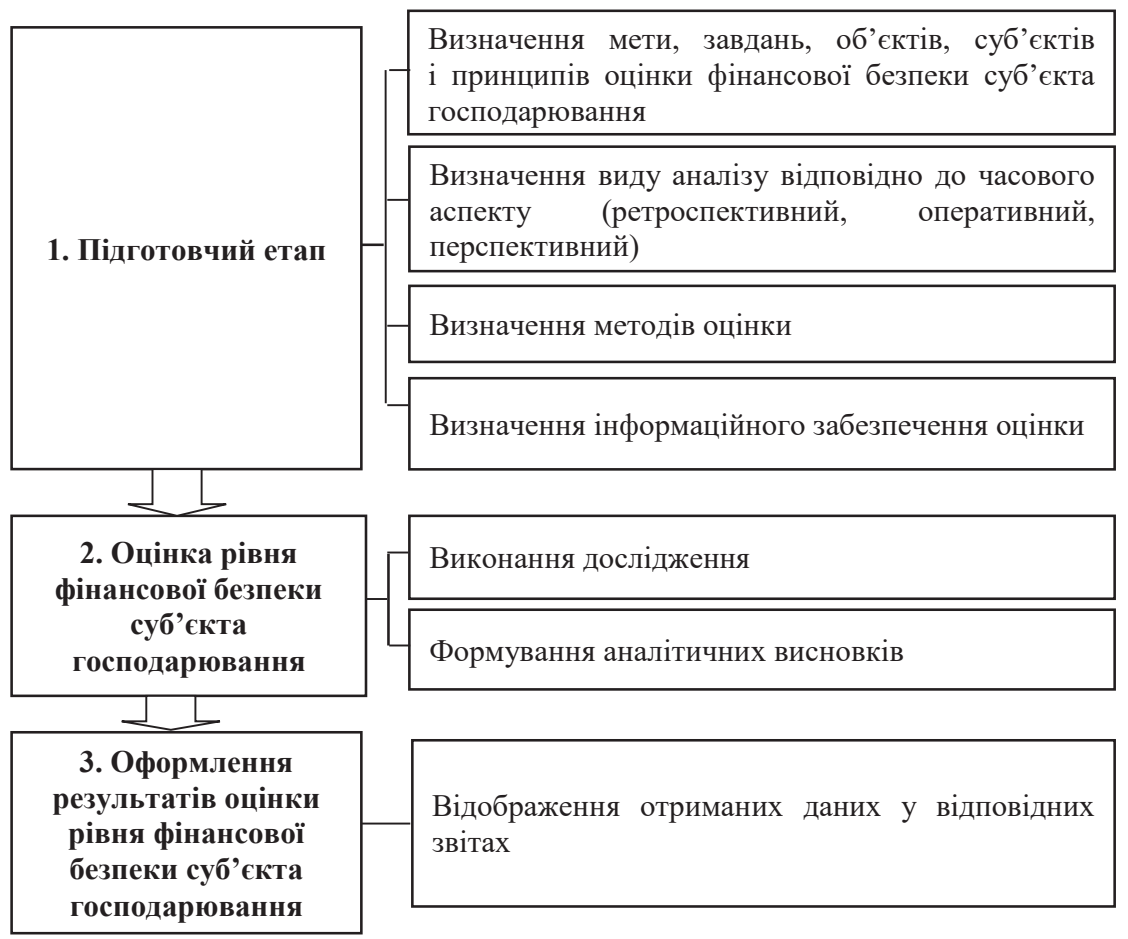

Рисунок 1 - Організаційна модель оцінки рівня фінансової безпеки суб'сктів підприємництва

Джерело: сформовано на основі [7, с. 237] 
1. Підготовчий етап (визначення мети, завдань, об'єктів, суб'єктів, методів та принципів оцінки рівня фінансової безпеки суб'єктів господарювання). Метою оцінки рівня фінансової безпеки суб'єкта господарювання є виявлення деструктивного впливу різноманітних чинників внутрішнього та зовнішнього середовища на його фінансову безпеку, розроблення й упровадження заходів захисту фінансових інтересів від виявлених загроз. Сформульована мета передбачає вирішення таких завдань:

- оцінка фінансового стану і динаміки розвитку суб'єкта господарювання;

- дослідження наявності негативних тенденцій розвитку підприємства;

- з'ясування причин, джерел, характеру дії деструктивних чинників на фінансову безпеку суб'єкта господарювання;

- прогнозування наслідків негативного впливу чинників внутрішнього та зовнішнього середовища на фінансово-господарську діяльність підприємства;

- розроблення заходів протидії загрозам фінансовій безпеці суб'єктів господарювання.

У процесі оцінювання рівня фінансової безпеки суб'єкта господарювання зацікавлені не лише внутрішні, а й зовнішні користувачі, адже інвестиційні та кредитні рішення ухвалюють на підставі інформації про фінансовий стан і рівень фінансової безпеки суб'єкта господарювання. Саме інтересами внутрішніх і зовнішніх користувачів зумовлені завдання та масштаб, у якому оцінюватимуть фінансову безпеку - чи загалом по підприємству, чи за його структурними підрозділами, чи за окремим проєктом (визначають об'єкт аналізу). Порівняльну характеристику зовнішнього та внутрішнього аналізу фінансової безпеки суб'єктів господарювання наведено в табл. 1.

Об'єктивність оцінки фінансової безпеки забезпечують урахуванням таких загальносистемних і спеціальних принципів, як системність, об'єктивність, адекватність, комплексність, взаємоузгодженість, універсальність, однозначність, результативність тощо.

Відповідно до часового аспекту, виділяють ретроспективний, оперативний та перспективний аналіз фінансової безпеки суб’єкта господарювання. Для того щоб управління фінансовою безпекою ділової одиниці відбувалося в режимі запобігання небажаним ситуаціям, а не в режимі виправлення наслідків, необхідно оперативно стежити за формуванням кожного показника фінансової безпеки, своєчасно виявляти відхи- лення фактичних значень від планових, коригувати ситуацію впровадженням організаційно-економічних заходів, порівнювати 3 даними минулих періодів та прогнозувати майбутні.

Методи оцінки рівня фінансової безпеки підприємств необхідно вибирати відповідно до визначеного об'єкта, мети та завдань такого аналізу, а також з урахуванням індивідуальних особливостей розвитку суб'єкта господарювання.

Згідно з вибраним методом дослідження визначають джерела необхідної інформації, виконують їі збирання та опрацювання з подальшим перетворенням на необхідну для оцінки фінансової безпеки суб'єкта господарювання.

Подальші етапи оцінки рівня фінансової безпеки охоплюють виконання розрахунків, формування на підставі отриманих значень відповідних висновків та відображення результатів у документальній формі.

У теорії та практиці фінансового менеджменту $є$ значна кількість підходів до оцінки рівня фінансової безпеки підприємств (рис. 2).

У першій методиці фінансову безпеку підприємства розглядають як складову частину його економічної безпеки і визначають на засадах визначення достатності власних чи позичених оборотних засобів для виробничо-збутової діяльності [4, с. 12-19]. Залежно від отриманих результатів виділяють п'ять зон фінансової стійкості, що відповідають п'яти рівням фінансової безпеки:

- абсолютна фінансова стійкість та абсолютна безпека (підприємству повністю достатньо власних оборотних коштів для функціонування);

- нормальна фінансова стійкість та нормальний рівень безпеки (підприємство використовує практично лише власні оборотні кошти для формування запасів i забезпечення витрат);

- нестійке фінансове становище та нестабільний рівень безпеки (підприємству недостатньо власних оборотних коштів, і воно має потребу у використанні середньо- та довготермінових позикових коштів);

- критичний фінансовий стан та критичний рівень безпеки (підприємство для фінансування діяльності використовує, крім середньо- та довготермінових кредитів, ще й короткострокові позики);

- кризовий фінансовий стан та кризовий рівень безпеки (підприємство не в змозі забезпечити фінансування діяльності ні власними, ні позиченими коштами, тобто перебуває на межі банкрутства).

\section{Таблиця 1 - Порівняльна характеристика зовнішнього та внутрішнього аналізу фінансової безпеки суб'єктів господарювання}

\begin{tabular}{|c|c|c|}
\hline \multirow{2}{*}{ Критерій порівняння } & \multicolumn{2}{|r|}{ Вид аналізу } \\
\hline & Зовнішній & Внутрішній \\
\hline Суб’єкти аналізу & $\begin{array}{l}\text { Власники підприємства, інвестори, } \\
\text { кредитори, учасники фінансового } \\
\text { ринку, державні органи }\end{array}$ & $\begin{array}{l}\text { Управлінський персонал підприємства (керівники, } \\
\text { служба фінансової безпеки, фінансові аналітики тощо) }\end{array}$ \\
\hline Основна ціль аналізу & $\begin{array}{l}\text { Оцінка фінансової спроможності } \\
\text { суб'єкта господарювання }\end{array}$ & $\begin{array}{l}\text { Виявлення та протидія деструктивним чинникам } \\
\text { впливу на фінансову безпеку суб’єкта господарювання }\end{array}$ \\
\hline Інформаційна база аналізу & $\begin{array}{l}\text { Фінансова звітність, зовнішні } \\
\text { додаткові джерела інформації }\end{array}$ & $\begin{array}{l}\text { Уся інформація про діяльність суб’єкта } \\
\text { господарювання }\end{array}$ \\
\hline Методи аналізу & Кількісні та якісні методи аналізу & Кількісні та якісні методи аналізу \\
\hline Періодичність виконання & Ретроспективний та перспективний & Оперативний, ретроспективний та перспективний \\
\hline
\end{tabular}




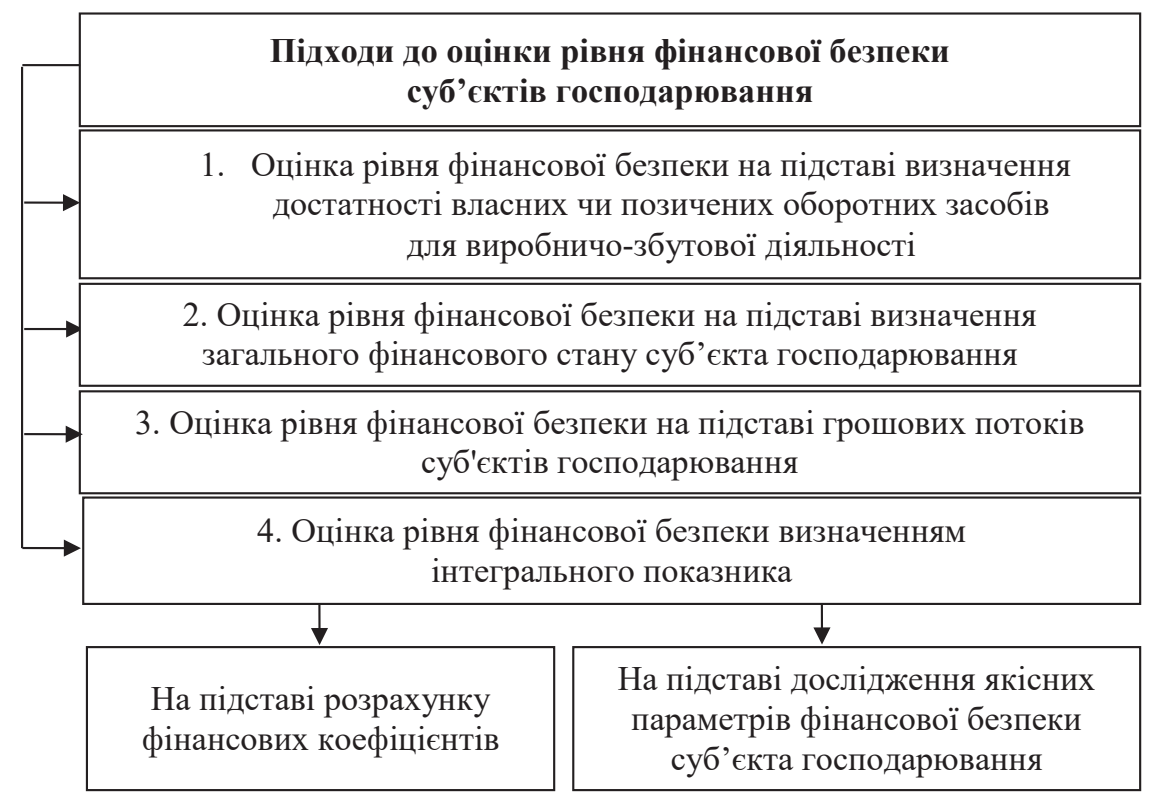

Рисунок 2 - Підходи до оцінки рівня фінансової безпеки суб'єктів господарювання

Ця методика оцінки фінансової безпеки не дає повного уявлення про рівень фінансової безпеки, оскільки поза увагою залишаються такі важливі показники фінансово-господарської діяльності, як основний капітал, прибуток, інвестиції. Зокрема, О. Ареф'єва [1, с. 98-103] наголошує, що фінансова безпека може бути визначена як стан найбільш ефективного використання корпоративних ресурсів, виражений у найкращих значеннях фінансових показників прибутковості і рентабельності бізнесу, якості управління та використання основних і оборотних коштів, структури його капіталу, норми витрат за цінними паперами, а також курсової вартості його цінних паперів як систематичного індикатора поточного фінансово-господарського становища i перспектив її технологічного та фінансового розвитку.

Оцінка рівня фінансової безпеки на підставі аналізу фінансового стану суб'єкта господарювання передбачає розрахунок низки ключових фінансових показників, які відображають результати функціонування всіх його підсистем та згруповані за такими напрямами (рис. 3).

Однак оцінка фінансової безпеки підприємства не може зводитися винятково до аналізу його фінансового стану, адже розглянуті вище фінансові показники дають лише часткову оцінку рівня фінансової

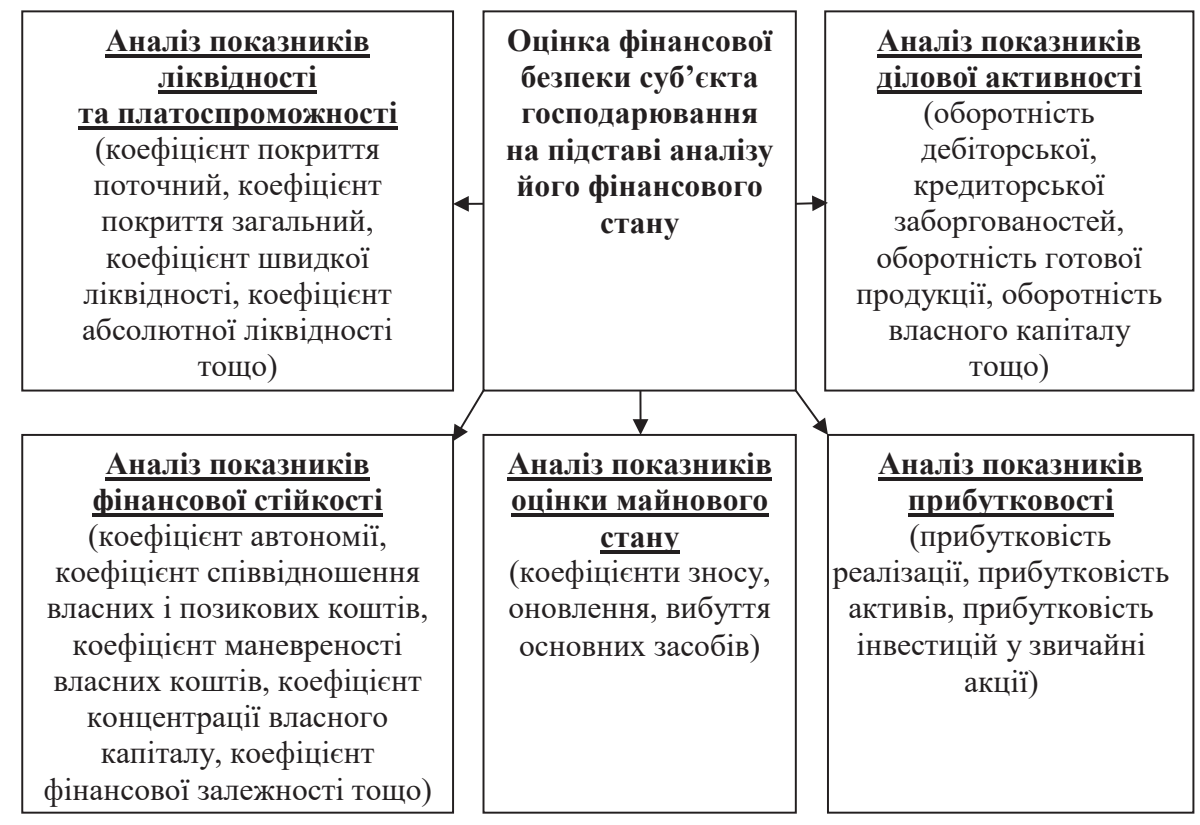

Рисунок 3 - Показники для визначення рівня фінансової безпеки суб'єктів господарювання 
безпеки суб'єкта підприємництва. Окрім того, у разі використання значної кількості коефіцієнтів, з одного боку, з'являється можливість максимально різнобічно проаналізувати діяльність суб'єкта підприємництва, однак, з іншого - велика кількість фінансових показників може створити неясність унаслідок суперечливих сигналів від результативних значень різних показників.

Серед інструментів оцінки рівня фінансової безпеки підприємств нами запропоновано використовувати матрицю динамічної фінансової рівноваги $[10$, с. $73-80]$, яка побудована на основі дослідження грошових потоків підприємств, а саме показника чистого грошового потоку в розрізі видів фінансовогосподарської діяльності підприємства (табл. 2).

Цей підхід зумовлений тим, що значення чистого грошового потоку є одним з індикаторів результативності господарської діяльності підприємства та значною мірою визначає його фінансовий стан. Аналіз цього показника в розрізі видів діяльності необхідно виконувати з урахуванням того факту, що додатне значення сукупного чистого грошового потоку не завжди $\epsilon$ гарантом фінансової стійкості підприємства, адже грошові потоки тісно пов'язують усі сфери діяльності підприємства: операційну, фінансову та інвестиційну.

Теоретично можливими є вісім варіантів позицій, проте найбільш реальними є такі: «Згортання діяльності» (комбінація секторів 1, 2, 3), «Поріг банкрутства» $(4,5,6)$, «Становлення» $(7,8,9)$, «Дилема» $(10$ $11,12)$, «Самофінансування» $(13,14,15)$, «Розвиток» $(16,17,18)$. Позиція «Згортання діяльності» $є$ найбільш характерною для суб'єкта господарювання, що планує завершити діяльність, оскільки немаэ грошових надходжень від операційної діяльності, водночас простежуються надходження грошових коштів від інвестиційної діяльності, що часто є свідченням розпродажу майна. Згідно з позицією «Поріг банкрутства», можна зробити висновок про критичне становище підприємства. Основний вид діяльності не є джерелом надходжень, надходження грошових коштів відбувається винятково завдяки залученим коштам (кредитам, позикам), а також реалізації необоротних активів, отриманих дивідендів, додаткової емісії акцій тощо. Із позиції «Становлення», випливає, що грошові кошти надходять на підприємство винятково від фінансової діяльності. Подібна структура грошових потоків допустима лише для новостворених суб'єктів господарювання на початковій стадії розвитку - залучення капіталу та інвестування для подальшого ведення операційної діяльності. Відповідно до позиції «Дилема», окрім грошових надходжень від операційної діяльності, підприємство отримує додаткові кошти від реалізованих довготермінових та поточних інвестицій, від реалізації необоротних активів тощо. Завдяки таким надходженням виконують розрахунки за зобов'язаннями 3 кредиторами, засновниками й іншими економічними суб'єктами. Щодо інвестиційної діяльності, то зазначимо, що додатне значення чистого грошового потоку може свідчити і про відмову підприємства вкладати грошові кошти в оновлення необоротних активів, фінансові інвестиції або ж про те, що такі вкладення є меншими, ніж сума надходжень від інвестиційної діяльності. У такій ситуації важко визначити, що саме стало причиною додатного значення чистого грошового потоку. Позиція «Самофінансування» свідчить про стійкий фінансовий стан господарського суб'єкта. Структура грошових потоків за такого варіанта дає змогу підприємству фінансувати інвестиційну діяльність, повертати залучені кошти, виплачувати відсотки винятково завдяки операційній діяльності. Позиція «Розвиток» $є$ ознакою стійкого становища підприємства за умови додатного значення алгебричної суми значень чистого грошового потоку всіх видів діяльності. У цьому разі можна зробити висновок, що підприємство має грошові надходження від операційної діяльності, а залучені кошти спрямовує на фінансування інвестиційної діяльності: придбання необоротних активів, реалізацію довготермінових та поточних інвестицій. Суб’єкт господарювання, фінансуючи інвестиційну діяльність, оновлює свої основні засоби, сприяє розширенню виробництва, модернізації тощо. Додатне значення чистого грошового потоку від фінансової діяльності може бути не лише свідченням отриманих кредитів, а й наслідком емісії акцій тощо.

Якщо показники чистого грошового потоку всіх видів діяльності мають додатне значення, то це може свідчити або ж про помилку в розрахунках, або ж про необдумане залучення грошових коштів та неефективне ïx використання. Ситуація, за якої чистий грошовий потік від усіх видів діяльності має від'ємне значення, $\epsilon$ неможливою, адже, не маючи надходжень грошових коштів, підприємство не може їх використовувати.

Описану методику нами рекомендовано застосовувати як допоміжний інструмент оцінки рівня фінансової безпеки суб'єктів господарювання, бо хоча показники грошових потоків і $є$ інформативними в разі дослідження рівня фінансової безпеки, та опиратися лише на їхнє значення не можна.

I. Мойсеєнко, М. Демчишин [6, с. 251-263], Л. Чаговець [8, с. 185-189; 9, с. 177-186] виділяють економікоматематичний підхід до оцінювання рівня фінансовоекономічної безпеки суб'єктів господарювання. Також серед науковців поширеним є підхід до оцінювання рівня фінансової безпеки суб'єктів господарювання шляхом обчислення інтегрального показника фінансової безпеки. Проте є розбіжності стосовно алгоритму його роз-

Таблиця 2 - Матриця динамічної фінансової рівноваги

\begin{tabular}{|c|c|c|c|c|}
\hline \multirow{2}{*}{ Показник } & \multicolumn{2}{|c|}{ Вид діяльності суб'єкта господарювання } & \multirow{2}{*}{ Позиція матриці } \\
\cline { 2 - 4 } & Операційна & Інвестиційна & Фінансова & «Згортання діяльності» \\
\hline \multirow{3}{*}{$\begin{array}{c}\text { Значення чистого } \\
\text { грошового } \\
\text { потоку }\end{array}$} & -1 & +2 & -3 & «Поріг банкрутства» \\
\cline { 2 - 4 } & -4 & +5 & +6 & «Становлення» \\
\cline { 2 - 4 } & -7 & -8 & -12 & «Дилема» \\
\cline { 2 - 4 } & +10 & +11 & -15 & «Самофінансування» \\
\cline { 2 - 4 } & +13 & -14 & +18 & «Розвиток» \\
\hline
\end{tabular}


рахунку. Зокрема, більшість дослідників схиляється до визначення інтегрального показника лише на підставі фінансових коефіцієнтів, що не повністю характеризує стан фінансової безпеки підприємства, адже суб'єкт господарювання, згідно з розрахованими фінансовими коефіцієнтами, може відповідати високому рівню фінансової безпеки і водночас унаслідок учинення фінансових шахрайств, витоку конфіденційної фінансової інформації може бути плановою жертвою протиправного захоплення, що повністю спростує присвоєний рівень безпечності. Тому оцінка рівня фінансової безпеки, на нашу думку, повинна охоплювати не лише фінансові індикатори розвитку, а й якісні параметри фінансової безпеки суб'єктів господарювання. Із цією метою нами пропонується комплексна методика оцінки рівня фінансової безпеки суб'єктів підприємництва (рис. 4).

На першому етапі оцінки рівня фінансової безпеки необхідно визначити перелік фінансових показників та їхні порогові значення. Наступний етап передбачає визначення експертним шляхом вагомості вибраних показників (у балах). Тобто якщо результуючий фінансовий показник відповідає умові, за якої забезпечується фінансова безпека, його значення трансформується в певну кількість балів, визначену експертами. Якщо досліджуваний показник не відповідає визначеній умові, то його значення трансформується в 0 балів.

Кількісні показники дають змогу визначити рівень фінансового менеджменту та надати оцінку роботи топ-менеджменту підприємства. Водночас за умов гібридних загроз такої оцінки недостатньо. Так, погоджуємося з думкою окремих науковців [5, с. 53-55], що застосування лише ресурсного підходу до оцінювання фінансової безпеки підприємства у сучасних умовах $\epsilon$ необгрунтованим, оскільки власне безпека трактується як здатність (спроможність) підприємства протистояти загрозам та забезпечувати його розвиток у майбутніх періодах. Тому пропонуємо вибір якісних показників фінансової безпеки здійснювати відповідно до визначеного переліку найбільш актуальних загроз фінансовій безпеці підприємства (табл. 3).

\begin{tabular}{|c|c|}
\hline \multicolumn{2}{|c|}{$\begin{array}{c}\text { Етапи комплексної оцінки рівня фінансової безпеки суб’єкта } \\
\text { господарювання }\end{array}$} \\
\hline \multicolumn{2}{|r|}{$\downarrow$} \\
\hline \multicolumn{2}{|c|}{$\begin{array}{c}\text { 1. Визначення переліку фінансових показників та їхніх порогових значень для } \\
\text { оцінки рівня фінансової безпеки суб'єкта господарювання }\end{array}$} \\
\hline \multicolumn{2}{|r|}{$\frac{1}{\nabla}$} \\
\hline \multicolumn{2}{|c|}{$\begin{array}{l}\text { 2. Визначення меж значень показників, за яких гарантована фінансова безпека суб’єкта } \\
\text { господарювання }\end{array}$} \\
\hline \multicolumn{2}{|r|}{$\nabla$} \\
\hline \multicolumn{2}{|c|}{$\begin{array}{l}\text { 3. Визначення експертним способом вагомості досліджуваних фінансових } \\
\text { показників }\end{array}$} \\
\hline \multicolumn{2}{|r|}{$\frac{1}{1}$} \\
\hline \multicolumn{2}{|c|}{$\begin{array}{l}\text { 4. Розрахунок результативних показників за кожним фінансовим індикатором і } \\
\text { визначення сукупного значення в балах }\end{array}$} \\
\hline \multicolumn{2}{|l|}{$\downarrow$} \\
\hline \multirow[t]{2}{*}{$\begin{array}{l}\text { 5. Визначення ключових загроз } \\
\text { фінансовій безпеці суб'єкта } \\
\text { господарювання }\end{array}$} & $\begin{array}{l}\text { 6. Визначення відповідних ідентифікованим } \\
\text { загрозам якісних оцінних показників } \\
\text { фінансової безпеки суб’єкта господарювання }\end{array}$ \\
\hline & $\downarrow$ \\
\hline \multicolumn{2}{|c|}{$\begin{array}{l}\text { 7. Присвоєння вагомості якісним оцінним показникам експертним } \\
\text { способом } \\
\end{array}$} \\
\hline & $\frac{1}{1}$ \\
\hline \multicolumn{2}{|c|}{ 8. Визначення значень якісних оціночних показників експертним шляхом } \\
\hline & $\downarrow$ \\
\hline \multicolumn{2}{|c|}{$\begin{array}{c}\text { 9. Розрахунок результативних показників за кожним якісним індикатором та } \\
\text { визначення сукупного значення в балах }\end{array}$} \\
\hline \multicolumn{2}{|r|}{$\downarrow$} \\
\hline \multicolumn{2}{|c|}{$\begin{array}{c}\text { 10. Розрахунок інтегрального показника оцінки рівня фінансової безпеки суб’єкта } \\
\text { господарювання підсумовуванням значень кількісних фінансових та якісних оцінних } \\
\text { показників }\end{array}$} \\
\hline & $\downarrow$ \\
\hline $\begin{array}{r}\text { 11. Побудова шкали значен } \\
\text { рівня фінансової }\end{array}$ & $\begin{array}{l}\text { рального показника та присвоєння відповідного } \\
\text { и - високий, середній, низький }\end{array}$ \\
\hline
\end{tabular}

Рисунок 4 - Етапи комплексної оцінки рівня фінансової безпеки суб'єктів підприсмництва 
Таблиця 3 - Загрози фінансовій безпеці суб'єктів господарювання та відповідні їм якісні показники оцінки рівня фінансової безпеки

\begin{tabular}{|c|c|}
\hline Загрози фінансовій безпеці суб’єктів господарювання & $\begin{array}{c}\text { Якісні показники оцінки фінансової безпеки } \\
\text { суб'сктів господарювання }\end{array}$ \\
\hline $\begin{array}{l}\text { Конфлікти інтересів між власниками, власниками і топ- } \\
\text { менеджментом суб’єкта господарювання }\end{array}$ & Оцінка рівня корпоративної культури \\
\hline $\begin{array}{l}\text { Низький рівень кадрової безпеки, що виявляється у } \\
\text { шахрайствах у фінансовій сфері }\end{array}$ & Оцінка роботи кадрової служби \\
\hline $\begin{array}{l}\text { Витік конфіденційної фінансової інформації, iï спотворення, } \\
\text { дезінформація }\end{array}$ & Оцінка роботи служби захисту інформації \\
\hline $\begin{array}{l}\text { Неналежне юридичне забезпечення укладення договорів та } \\
\text { контрактів суб'єктом господарювання }\end{array}$ & Оцінка роботи юридичної служби \\
\hline Рейдерство, недобросовісна конкуренція, ділове шпигунство & Оцінка роботи служби управління фінансовою безпекою \\
\hline
\end{tabular}

Наступні етапи оцінки рівня фінансової безпеки суб'єкта господарювання передбачають експертну оцінку вагомості якісних показників та обчислення їхніх значень. Після цього необхідно розрахувати сукупний бальний показник за всіма якісними параметрами. На завершальному етапі пропонованої комплексної оцінки необхідно здійснити узагальнене оцінювання рівня фінансової безпеки підприємства підсумуванням сукупних бальних оцінок кількісних та якісних індикаторів із формуванням шкали значень інтегрального показника й присвоєння відповідного рівня фінансової безпеки: високий, середній, низький.

Розрахунок рівня фінансової безпеки (РФБ) виконують за такими формулами:

$$
\begin{gathered}
P \Phi Б=\sum_{i=1}^{n} c_{i} d_{i} \\
c_{i}=\frac{\sum_{j=1}^{m} a_{i j}}{m} \\
d_{i}=\frac{\sum_{j=1}^{m} b_{i j}}{m},
\end{gathered}
$$

\section{Список використаних джерел:}

1. Ареф'єва О.В. Економічні основи формування фінансової складової економічної безпеки. Актуальні проблеми економіки. 2009. № 1(91). C. 98-103.

2. Бланк И.А. Управление финансовой безопасностью предприятия. Киев : Эльга, Ника-Центр, 2004. 784 с.

3. Срмошенко М.М., Горячева К.С. Фінансова складова економічної безпеки: держава і підприємство : монографія. Київ : Національна академія управління, 2010. 232 c.

4. Ильяшенко С.Н. Составляющие экономической безопасности предприятия и подходы к их оценке. Актуальні проблеми економіки. 2003. № 3. С. 12-19.

5. Кокнаєва М.О. Особливості формування методичного інструментарію дослідження фінансово-економічної безпеки торговельних підприємств. Економічний часопис-XXI. 2012. № 5-6. С. 53-55.

6. Мойсеєнко І.П., Демчишин М.Я. Економетричний аналіз стану економічної безпеки суб'єктів господарювання. Науковий вісник Львівського держсавного університету внутрішніх справ. 2010. Вип. 3. С. 251-263.

7. Крупка М.І., Яструбецька Л.С. Фінансова безпека суб’єктів господарювання : підручник. Львів : ЛНУ імені Івана Франка, 2018. 320 с.

8. Чаговець Л.О. Застосування апарату нечіткої логіки для оцінки рівня економічної безпеки підприємства. Сучасні та перспективні методи і моделі управління в економіці : монографія : у 2-х ч. / за ред. д-ра екон. наук, проф. А.О. Спіфанова. Суми : ДВНЗ «УАБС НБУ», 2008. Ч. 1. С. 177-186.

9. Чаговець Л.О. Модель оцінки рівня фінансової складової економічної безпеки підприємства. Математичні моделі та інформаційні технологї в сучасній економіüi : монографія / за ред. д-ра екон. наук, проф. А.О. Спіфанова. Суми : УАБС НБУ, 2007. 246 с.

10. Яструбецька Л.С., Підхомний О.М. Індикатори оцінки рівня фінансової безпеки суб'єктів господарювання. Збірник наукових праць Луцького державного технічного університету. Серія «Облік і фінанси». 2007. Вип. 4(16). Ч. 2. С.73-80.

\section{References:}

1. Arefyeva O.V. (2009) Ekonomichni osnovy formuvannya finansovoyi skladovoyi ekonomichnoyi bezpeky [Economic bases of formation of a financial component of economic safety]. Aktual'ni problemy ekonomiky, 1(91). (in Ukrainian) 
2. Blank I.A. (2004) Upravleniye finansovoy bezopasnost'yu predpriyatiya [Enterprise financial security management]. Kyiv: El'ga, Nika-Tsentr. (in Russian)

3. Yermoshenko M.M., Horyacheva K.S. (2010) Finansova skladova ekonomichnoyi bezpeky: derzhava i pidpryyemstvo: monohrafiya [Financial component of economic security: state and enterprise]. Kyiv: Natsional'na akademiya upravlinnya. (in Ukrainian)

4. Il'yashenko S.N. (2003) Sostavlyayushchiye ekonomicheskoy bezopasnosti predpriyatiya i podkhody k ikh otsenke [Components of the economic security of an enterprise and approaches to their assessment]. Aktual'ni problemi yekonomíki, 3, 12-19. (in Russian)

5. Koknayeva M.O. (2012) Osoblyvosti formuvannya metodychnoho instrumentariyu doslidzhennya finansovo-ekonomichnoyi bezpeky torhovel'nykh pidpryyemstv [Features of formation of methodical tools of research of financial and economic safety of the trade enterprises]. Ekonomichnyy chasopys-XXI, 5-6, 53-55. (in Ukrainian)

6. Moyseyenko I.P., Demchyshyn M.Ya. (2010) Ekonometrychnyy analiz stanu ekonomichnoyi bezpeky sub"yektiv hospodaryuvannya [Econometric analysis of the state of economic security of economic entities]. Naukovyy visnyk L'vivs'koho derzhavnoho universytetu vnutrishnikh sprav. Seriya «Ekonomichna», vol. 3, 251-263. (in Ukrainian)

7. Finansova bezpeka sub"yektiv hospodaryuvannya (2018) [Financial security of business entities]. L'viv: LNU imeni Ivana Franka. (in Ukrainian)

8. Chahovets' L.O. (2008) Zastosuvannya aparatu nechitkoyi lohiky dlya otsinky rivnya ekonomichnoyi bezpeky pidpryyemstva. Suchasni ta perspektyvni metody i modeli upravlinnya v ekonomitsi [Application of fuzzy logic apparatus to assess the level of economic security of the enterprise. Modern and promising methods and models of management in the economy]. Sumy: UABS NBU, ch. 1, 177-186. (in Ukrainian)

9. Chahovets' L.O. (2007) Model' otsinky rivnya finansovoyi skladovoyi ekonomichnoyi bezpeky pidpryyemstva. Matematychni modeli ta informatsiyni tekhnolohiyi $\mathrm{v}$ suchasniy ekonomitsi [Model for assessing the level of the financial component of economic security of the enterprise. Mathematical models and information technologies in modern economy]. Sumy: UABS NBU. (in Ukrainian)

10. Yastrubets'ka L.S., Pidkhomnyy O.M. (2007) Indykatory otsinky rivnya finansovoyi bezpeky sub"yektiv hospodaryuvannya [Indicators for assessing the level of financial security of economic entities]. Zbirnyk naukovykh prats' Luts'koho derzhavnoho tekhnichnoho universytetu. Seriya «Oblik i finansy», vol. 4(16), 73-80. (in Ukrainian)

Yastrubetska Lesya

Lviv National University named Ivan Franko

\section{COMPLEX METHODOLOGY OF ASSESSING THE LEVEL OF FINANCIAL SECURITY OF ENTREPRENEURSHIP ENTITIES IN UKRAINE UNDER CONDITIONS OF HYBRID THREATS}

In the context of the Covid-19 pandemic, both the world economic system and the financial system of each state and business unit in particular have undergone significant changes. Quarantine measures have contributed to an even more rapid introduction of information technology into financial processes, leading to the emergence of an updated format for the functioning of business entities with the simultaneous spread and new threats to their financial security. In this context, the article substantiates the need for effective management of financial security of business entities, a key stage of which is the assessment of the level of financial security. The comparative analysis of various scientific approaches to such estimation is carried out, in particular on the basis of definition of sufficiency of own or borrowed working capital; based on the analysis of the general financial condition of the enterprise; based on the calculation of cash flows and by determining the integrated indicator. The article proposes an author's method of assessing the level of financial security of business entities, which takes into account not only the financial performance of the enterprise, but also the qualitative parameters of each of the components of financial security, based on the analysis of threats to financial security. To such qualitative indicators the author suggests to include the following: the level of corporate culture at the enterprise according to the evaluation criterion of conflicts of interest, the quality of human resources according to the evaluation criterion of financial fraud, the quality of IT - the leakage or distortion of information, quality of work legal service - according to the evaluation criterion of the facts of improper conclusion of agreements and contracts, the quality of the financial security service - according to the evaluation criterion of the presence of facts of raiding, unfair competition, business espionage. In addition, emphasis is placed on the need to take into account the principles of systemicity, integration, accessibility, constructiveness and strategic vision when assessing the financial security of economic entities. The article formalizes a set of stages and measures to assess the financial security of enterprises in the form of an organizational model that will increase the efficiency of financial security management of business units and reduce labor and time costs for its implementation.

Key words: financial security of business entities, assessment of the level of financial security of enterprises, the matrix of dynamic financial equilibrium, net cash flow of the enterprise in terms of operating, financial, investment activities, organizational model for assessing the level of financial security of economic entitie.

JEL classification: M13 